\section{Nutrient Uptake and Distribution in a Mature 'Pinot noir' Vineyard}

\author{
R. Paul Schreiner and Carolyn F. Scagel \\ U.S. Department of Agriculture, Agricultural Research Service, Horticultural \\ Crops Research Laboratory, 3420 NW Orchard Avenue, Corvallis, OR 97330
}

John Baham

Oregon State University, Department of Crop and Soil Science, 3125 ALS, Corvallis, OR 97331

Additional index words. calcium, magnesium, nitrogen, phosphorus, potassium, roots, soil, Vitis

Abstract. The nutrient uptake and distribution patterns for $\mathrm{N}, \mathrm{P}, \mathrm{K}, \mathrm{Ca}$, and Mg were determined in mature (23 to 24 year old), field-grown, rainfed grapevines (Vitis vinifera L. 'Pinot noir') growing in a red hill soil in Oregon in 2001 and 2002. Biomass, nutrient concentrations, and nutrient contents of all plant organs, including roots, were determined on 14 sampling dates over 2 years. There was no seasonal change in the standing biomass of primary roots (fine feeder roots), small woody $(<4 \mathrm{~mm}$ diameter) or large woody ( $>4 \mathrm{~mm}$ diameter) roots. Trunk biomass also did not change during the 2 years, but all other vine organs showed significant seasonal changes in biomass. The rate of $\mathrm{N}$ uptake was greatest at bloom, when remobilization from reserves was also high. Nitrogen was also taken up after leaf fall in 2001, but not in 2002, when an early frost occurred before soil moisture recovery by fall rains. Uptake of $\mathrm{N}, \mathrm{K}$, and $\mathrm{Ca}$ from soil was similar between years, even though canopy demand for $\mathbf{N}$ and $\mathrm{K}$ was greater in 2002 (significantly larger crop). Phosphorus uptake from soil was lower in 2002 than in 2001, which was most likely due to the drier conditions in 2002. A greater quantity of canopy $N, K$, and especially $P$ was supplied from stored reserves in the drier 2002 growing season. About $50 \%$ of canopy requirements for $\mathrm{N}$ and $P$ were remobilized from reserves in the trunk and roots by the time of fruit maturity in 2002. Only $15 \%$ of canopy $\mathrm{K}$ and $<\mathbf{5 \%}$ of canopy Ca or $\mathrm{Mg}$ came from stored reserves in 2002. Our findings indicate that nonirrigated grapevines grown in Oregon acquire nutrients from soil earlier in the growing season and have a greater reliance on stored reserves of $\mathrm{N}$ and $\mathbf{P}$ than reported in previous studies from other growing regions. Replenishment of nutrient reserves occurred to large extent during the postharvest period. Rainfed vineyards in Oregon may require different nutrient management practices than irrigated vineyards, since low soil moisture may limit summer uptake of $P$.

Nutrient uptake and distribution has been studied in both potted and field-grown grapevines (recently reviewed by Conradie, 2005). Most studies have focused only on nitrogen, with few reports including other important plant nutrients. The quantity of nutrients required by grapevines to produce a quality crop is low in comparison to most other horticultural plants. Estimates of annual grapevine $\mathrm{N}$ requirements vary considerably, ranging from about $30 \mathrm{~kg} \cdot \mathrm{ha}^{-1}$ (Bates et al., 2002; Conradie, 1980, 1986) to about $80 \mathrm{~kg} \cdot \mathrm{ha}^{-1}$ (Hanson and Howell, 1995; Löhnertz, 1991; Williams, 1987, 1991). The quantity of $\mathrm{N}$ that typically leaves the vineyard

Received for publication 28 Oct. 2005. Accepted for publication $22 \mathrm{Dec}$. 2005. The authors greatly appreciate the technical support of Keiko Mihara, Matthew Scott, Stepfanie Lair, John Carter, Charles Hand, Corin Schowalter, Diane Cygan, Jeff Cygan, and Scott Robbins. We also wish to thank four anonymous reviewers for providing helpful suggestions that improved this manuscript. This research was supported, in part, by a grant from the Oregon Wine Advisory Board. Mention of a trademark, proprietary product, or vendor does not constitute a guarantee or warranty of the product by the U.S. Dept. of Agriculture and does not imply its approval to the exclusion of other products or vendors that also may be suitable.

${ }^{1}$ Corresponding author; e-mail schreinr@science. potted vines (Conradie, 1981a).

While the nutrient uptake capacity of vines can increase shortly after budbreak, the majority of nutrient uptake from soil has most often been found to occur between bloom and veraison in both winegrapes (Vitis vinifera L.) and Concord grapes (Vitis labrusca L.) (Bates et al., 2002; Conradie, 1980, 1981a; Hanson and Howell, 1995; Löhnertz, 1991). Studies employing isotopically labeled $\mathrm{N}$ fertilizers generally agree with this timeframe for maximal $\mathrm{N}$ uptake, showing higher rates of label incorporation when fertilizers are applied at bloom, as compared to budbreak (Conradie, 1986; Peacock et al., 1989; Vos et al., 2004). Increasing rates of $\mathrm{N}$ uptake after bloom also coincides with the time of new root growth reported in some studies (Freeman and Smart, 1976; Mullins et al. 1992; Van Zyl, 1988), suggesting that the capacity for nutrient uptake depends on the production of new roots.

Recent work in a rainfed 'Pinot noir' vineyard in Oregon showed a near constant length of fine roots in soil over the course of the growing season (no peak of root growth at bloom), with the only increase in fine root length occurring in the fall (Schreiner, 2005). Specific colonization patterns by arbuscular mycorrhizal fungi(AMF) in those roots suggested that nutrient uptake could be occurring anytime from budbreak in early May until a month after leaf fall in December. The frequency of arbuscules (the site of nutrient transfer in mycorrhizas) in the fine roots of these vines was very high throughout this entire time period. If we also consider that the average lifespan of grapevine fine roots is about 4 to 6 months (Anderson et al., 2003), nutrient uptake could occur months after a root is born. Indeed, new roots initiated in late summer or early fall appear to have longer lifespans than roots initiated in early summer (Anderson et al., 2003), suggesting that these late season roots can function in nutrient uptake in the following growing season. These observations combined with the findings of greater $\mathrm{N}$ uptake by grapevines before bloom reported in some studies (Araujo and Williams, 1988; Mullins et al., 1992), indicates that peak times of nutrient uptake by grapevines may not depend on new root growth and cannot be predicted based on characterizing root growth patterns.

The present study was undertaken to investigate nutrient uptake and distribution of mature vines (23 to 24 years old) grown without irrigation in a region with low summer rainfall common to western Oregon vineyards. Whole vine nutrient uptake studies that have been conducted over the entire growing season (budbreak to leaf fall) have been carried out in irrigated vineyards or pots or in regions that receive significant summer rainfall (Araujo and Williams, 1988; Bates et al., 2002; Conradie, 1980, 1981a; Hanson and Howell, 1995; Löhnertz, 1991). Most studies have also been conducted on relatively young vines. We suspected that the nutrient requirements of vines grown in Oregon would be lower than other viticultural regions owing to the low yields (5000 to $6000 \mathrm{~kg} \cdot \mathrm{ha}^{-1}$ ) typical in the region.

\section{Materials and Methods}

Vineyard description and management

The study was conducted on mature, 'Pinot noir' (Vitis vinifera L., Pommard clone, FPS 
Table 1. Weather conditions and phenology of 'Pinot noir' grapevines in a western Oregon vineyard in 2001 and 2002.

\begin{tabular}{|c|c|c|c|c|c|c|c|c|}
\hline & \multicolumn{2}{|c|}{$\begin{array}{c}\text { Mean monthly } \\
\text { temp }\left({ }^{\circ} \mathrm{C}\right)^{\mathrm{z}}\end{array}$} & \multicolumn{2}{|c|}{$\begin{array}{c}\mathrm{GDD}^{\mathrm{z}} \\
\left(>10^{\circ} \mathrm{C}\right)\end{array}$} & \multicolumn{2}{|c|}{$\begin{array}{c}\mathrm{ET}_{0} \\
(\mathrm{~mm})^{\mathrm{y}}\end{array}$} & \multicolumn{2}{|c|}{$\begin{array}{c}\text { Phenology } \\
\text { date }\end{array}$} \\
\hline & 2001 & 2002 & 2001 & 2002 & 2001 & 2002 & 2001 & 2002 \\
\hline April & 8.7 & 10.3 & 25 & 36 & 75 & 96 & Budbreak 20 Apr. & Budbreak 16 Apr. \\
\hline May & 13.6 & 11.9 & 121 & 87 & 163 & 126 & & \\
\hline June & 14.7 & 16.1 & 147 & 187 & 144 & 163 & Bloom 20 June & Bloom 23 June \\
\hline July & 18.4 & 19.9 & 264 & 311 & 203 & 225 & & \\
\hline August & 19.2 & 19.2 & 288 & 286 & 168 & 203 & Veraison 1 Sept. & Veraison 25 Aug. \\
\hline September & 17.1 & 17.3 & 217 & 223 & 128 & 136 & Harvest 28 Sept. & Harvest 25 Aug. \\
\hline October & 11.4 & 11.3 & 65 & 71 & 60 & 72 & & \\
\hline November & 8.7 & 7.8 & 22 & 8 & 18 & 24 & Leaf fall 12 Nov. & Leaf fall ${ }^{\mathrm{w}} 6$ Nov. \\
\hline Cumulative $^{\mathrm{x}}$ & & & 1033 & 1074 & 830 & 885 & & \\
\hline
\end{tabular}

${ }^{\mathrm{z}}$ Mean monthly temperature and total monthly growing degree days (GDD).

${ }^{y}$ Kimberly-Penman evapotranspiration from Corvallis, OR (http://www.usbr.gov/pn/agrimet/) weather station.

${ }^{\mathrm{x}}$ Cumulative data between budbreak and harvest for each year.

${ }^{w}$ Hard frost $\left(-8^{\circ} \mathrm{C}\right)$ occurred on 2 Nov. 2002.

91) grapevines during 2001 and 2002 at the Oregon State University, Woodhall Research Vineyard located in Alpine, Ore. $\left(44^{\circ} 20^{\prime} \mathrm{N}\right.$, $\left.123^{\circ} 24^{\prime} \mathrm{W}\right)$. The site was chosen because it is representative of typical western Oregon vineyards producing 'Pinot noir' grapes, and managed in general accordance with practices used by growers in the region. The vineyard is located on a south-facing slope, $200 \mathrm{~m}$ above sea level, and receives about $1100 \mathrm{~mm}$ rainfall per annum primarily in the fall, winter, and spring. The soil is a Jory series (fine, mixed, active, mesic Xeric Haplohumult) with a surface $\mathrm{pH}$ of 5.3 to 5.6. Vines were planted in 1978 (23 years old in 2001) on their own roots and grown without irrigation for the past 20 years. Vine spacing is $1.82 \times 2.74 \mathrm{~m}(2005$ vines/ha $)$. Other characteristics of this vineyard can be found in Schreiner (2005).

Vines were managed differently during the 2 years of this study. The largest difference was in the crop load that vines carried to maturity in each year. Fruit was thinned two times during the 2001 season (at lag phase on 15 Aug., and again after veraison on 10 Sept.) removing an average of 19 clusters per vine. Fruit was thinned only once in 2002 (at lag phase on 7 Aug.) removing an average of 14 clusters per vine. Nitrogen fertilizer $\left[\mathrm{Ca}\left(\mathrm{NO}_{3}\right)_{2}\right]$ was broadcast in the vineyard on 15 May 2001 at a rate of $17 \mathrm{~kg} \cdot \mathrm{ha}^{-1} \mathrm{~N}$. Boron (Solubor, U.S. Borax, Valencia, Calif.) was applied to the foliage with the first 2 mildew sprays (sulfur) of the year in 2001 at a rate of $1.1 \mathrm{~kg} \cdot \mathrm{ha}^{-1} \mathrm{~B}$. Neither fertilizer was applied in 2002.

Vine sampling procedures. Whole vines were randomly selected, destructively harvested, and separated into nine plant parts (fine feeder roots, small woody roots $<4 \mathrm{~mm}$ diameter, large woody roots $>4 \mathrm{~mm}$ diameter, trunks, woody canes, stems, petioles, leaf blades, and flower/fruit clusters) on each of 14 sampling dates over two years. All plant parts were placed in plastic bags and stored in coolers until transport to the laboratory. No vines were sampled adjacent to a previously harvested vine or from row ends or edge rows.

In 2001, four vines were sampled on each of seven dates at about monthly intervals between budbreak and leaf fall. Vines were sampled on 20 Apr. (budbreak), June 4 (prebloom), 8 July (postbloom), 4 Aug. (preveraison), 5 Sept. (veraison), 28 Sept. (harvest) and 12 Nov. (leaf fall) 2001. In 2002, six vines were sampled at each specific phenological stage of pruning, budbreak, bloom, veraison, harvest, leaf fall, and again at pruning in 2003 (see Table 1 for sampling dates).

Root systems were not entirely removed at each sampling date. Instead, roots were estimated by removing a portion of the root system. In 2001, the square area that was theoretically occupied by each vine $(1.82 \times$ $2.74 \mathrm{~m}$ ) was divided into 24 equal blocks (46 $\times 46 \mathrm{~cm}$ ) and roots were extracted from the soil removed from each of 4 blocks dug to a depth of about $1 \mathrm{~m}$ per vine (Fig. 1). Each soil block sampled represented a different location with respect to distance from the vine trunk, and with respect to the varying vineyard floor management practices (A,B,C, or D locations in Fig. 1). The specific block sampled at each location (A, B, C, and D) was randomly selected for every vine sampled. Root biomass values obtained from A and B blocks were multiplied by 4 and those from $\mathrm{C}$ and D blocks were multiplied by 8 to obtain an estimate of the total. We expected that the data thus obtained for individual vine replications would be variable (due to nonuniform root distribution for each vine), but assumed that a good estimate of the mean would be obtained on a given sampling date. Roots were separated from soil by hand, after spreading
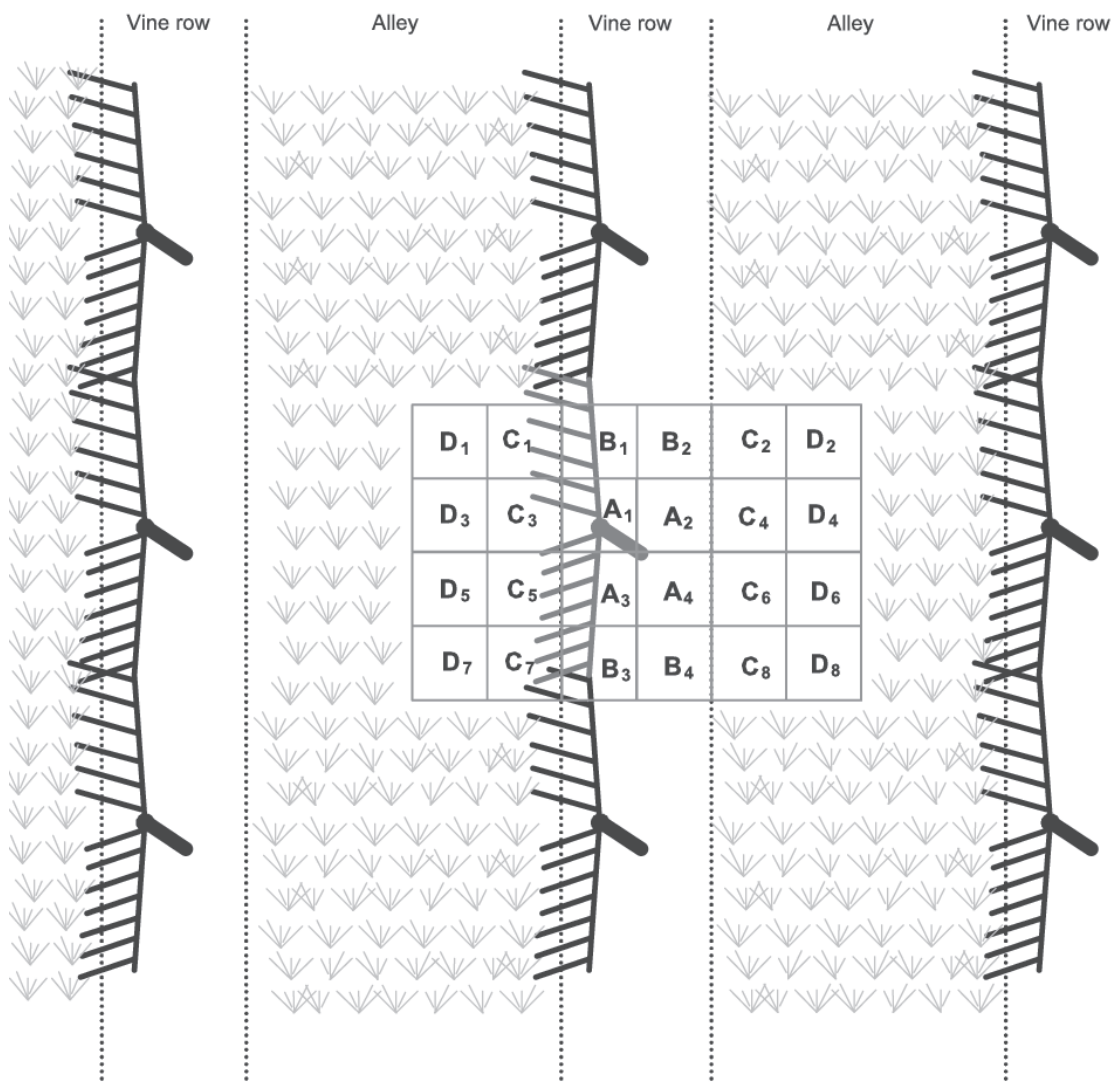

Fig. 1. Grid sampling system employed to estimate root system biomass in 2001. The sampled vine is shown in grey color and each of 24 grids $(46 \times 46 \mathrm{~cm})$ are labeled with respect to vine location and vineyard floor management practices. (A and $\mathbf{B}$ ) Grids are in the herbicide-treated vine row at different distances from the vine. ( $\mathbf{C}$ and $\mathbf{D})$ Grids in the alley at different distances from the vine. One grid (soil block) was randomly selected and sampled from each location $(\mathbf{A}, \mathbf{B}, \mathbf{C}$, or $\mathbf{D})$ for each vine destructively harvested. 


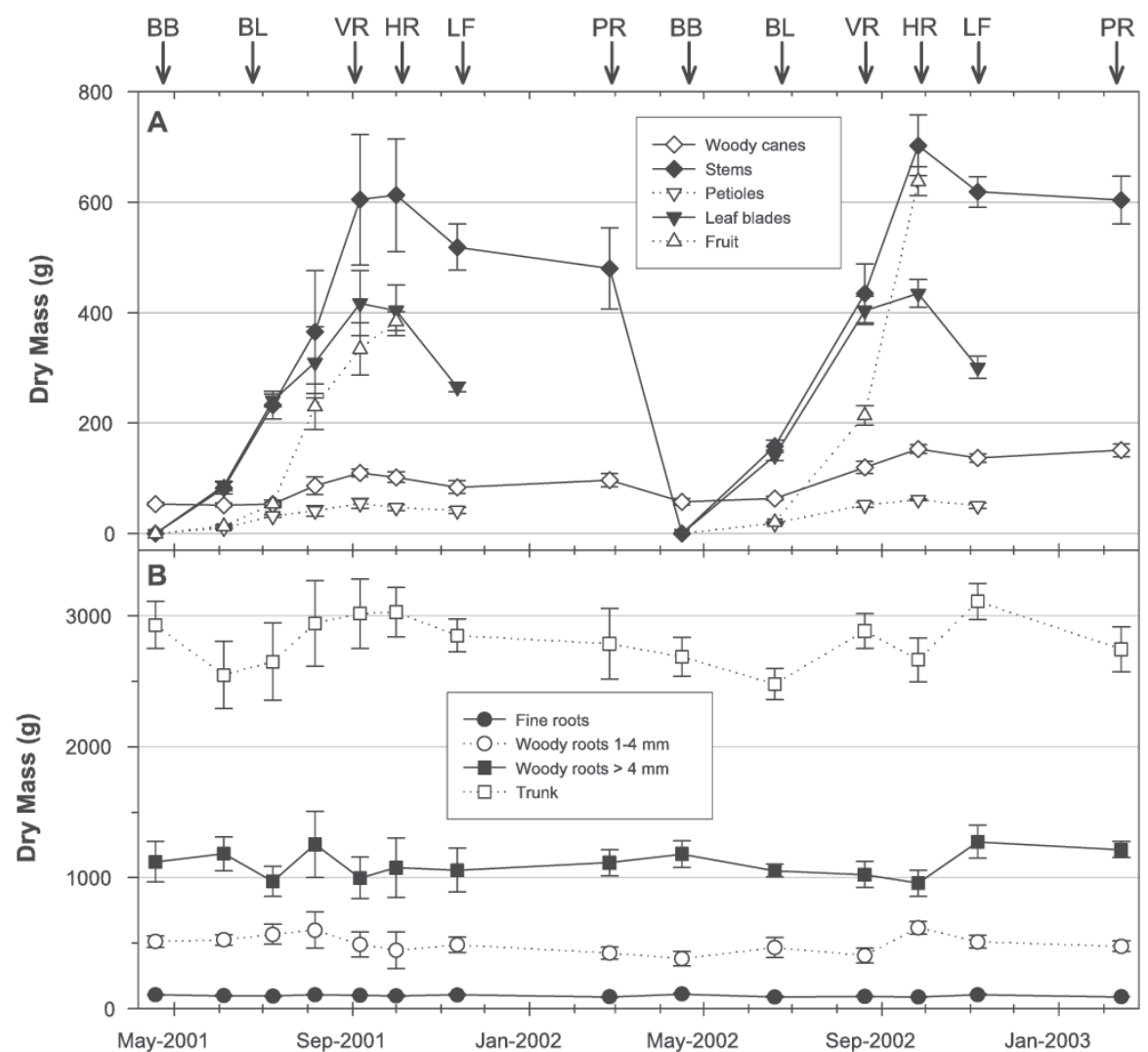

the soil out over a large surface area, working with small aliquots of soil at a time. Because some fine roots were overlooked during this process, the quantity of fine roots that were still remaining in the soil was determined as follows. The volume of soil from each block

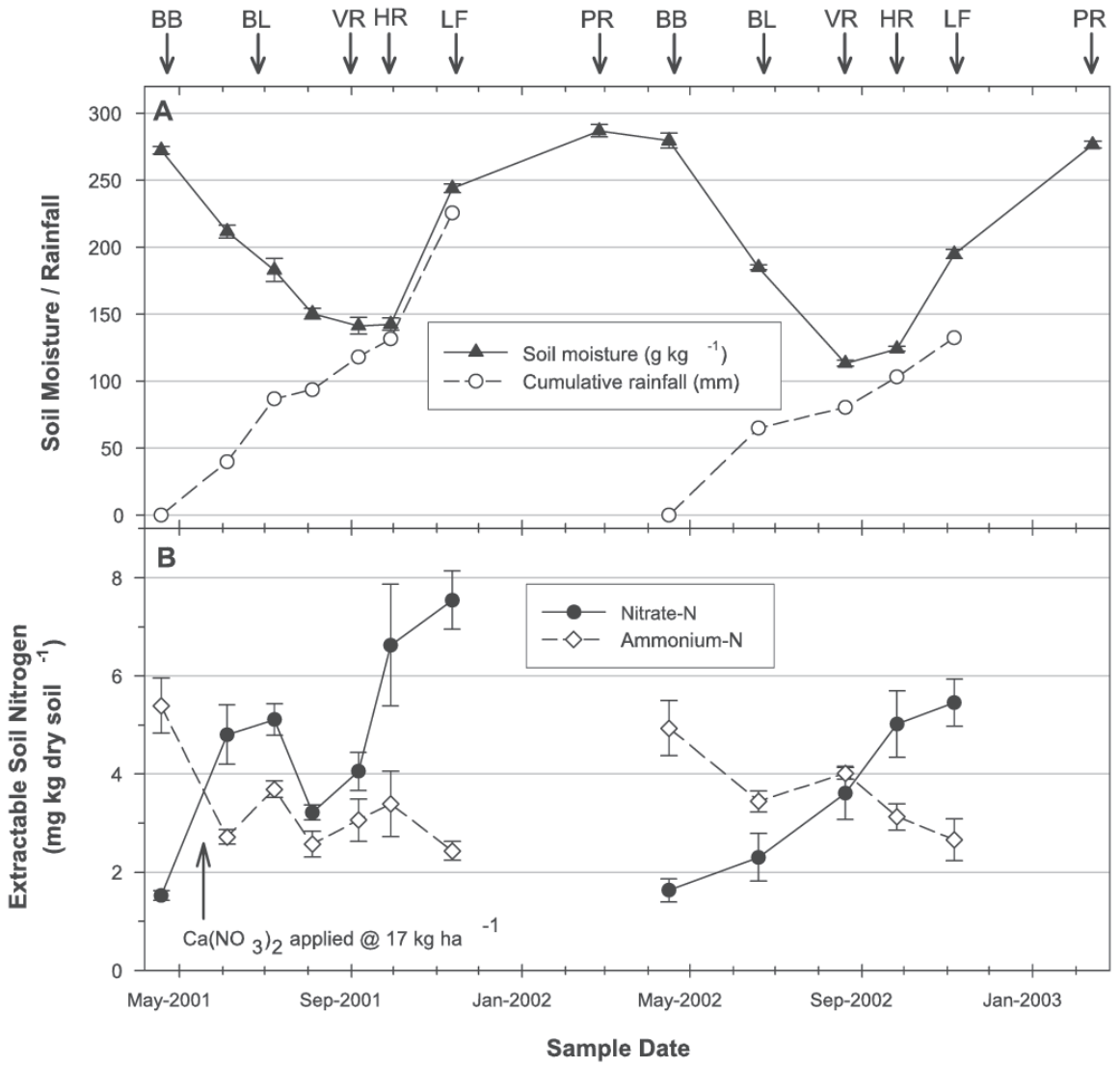

Fig. 2. Changes in dry mass of 'Pinot noir' plant parts in a western Oregon vineyard in 2001 and 2002. Dry mass of above-ground plant fractions that varied significantly $(p<0.05)$ by sample date (A). Dry mass of root fractions and trunks that did not vary significantly $(p>0.05)$ by sample date (B). Data points represent means with standard errors at each sampling date $(n=4,2001 ; n=$ $6,2002)$. Arrows at the top of graph indicate the time of budbreak (BB), bloom (BL), veraison (VR), fruit maturity or harvest (HR), leaf fall (LF), and pruning (PR)

processing) represented $<15 \%$ of the total fine root mass and were typically comprised of very small ( $<5 \mathrm{~mm}$ length) root fragments.

In 2002, fine roots and small woody roots $(<4 \mathrm{~mm})$ were extracted from 18 -cm-diameter soil cores taken at random locations with respect to the area occupied by each vine. Soil from six cores was removed for each sampled vine (three from within the weed-free vine row and three from the alleyway) to a depth of $1 \mathrm{~m}$. Fine roots and small woody roots extracted from these large core samples were multiplied by an appropriate factor to estimate their total mass per vine. Large woody roots ( $>4 \mathrm{~mm}$ ) were obtained by carefully exposing roots at the base of each vine and excavating individual roots until all roots were obtained. Care was taken to minimize severing roots during excavation by first following surface (horizontal) roots and working down to roots located in deeper soil layers. Prior work in this vineyard showed that exceptionally few roots were found below a depth of $1 \mathrm{~m}$, because of the presence of weathered bedrock(Crhorizon) between depths of 0.6 to $1.0 \mathrm{~m}$ (Schreiner, Baham and Gallagher, unpublished).

The total fresh mass of all plant parts was determined at each sampling date and subsamples were retained for analysis, as needed. A separate subsample of fine roots (about $0.5 \mathrm{~g}$ fresh mass) was stored in $50 \%$ ethanol : $10 \%$ acetic acid, and later cleared and stained to determine colonization by arbuscular mycorrhizal fungi, as in Schreiner (2003). Subsamples from all plant parts were washed with distilled water and oven dried at $70{ }^{\circ} \mathrm{C}$ until constant dry weight was obtained. Berries from fruit clusters sampled at harvest were removed from the rachis after oven drying for $7 \mathrm{~d}$ and dried for another 14 to $21 \mathrm{~d}$ to facilitate complete drying. Subsamples for analysis were obtained as follows: leaf blades were placed in large bag, mixed, and about $20 \%$ were retained; stems (green canes) were cut into about $15 \mathrm{~cm}$ lengths, mixed and about $20 \%$ were retained; vine trunks were sampled by removing a thin cross-section (about 3 to $4 \mathrm{~mm}$ thick) every $15 \mathrm{~cm}$ along the length of the trunk with a power saw (taking precaution that each disc had complete covering of bark);

Fig. 3. Soil moisture and rainfall (A), and soil test nitrogen concentrations $(\mathbf{B})$ in a western Oregon vineyard in 2001 and 2002. Data points (except rainfall, $\mathrm{n}=1$ ) represent means with standard errors at each sampling date $(n=4,2001 ; n=$ $6,2002)$. Arrows as in Fig. 2. Rainfall before budbreak (1 Jan. to budbreak) was $188 \mathrm{~mm}$ in 2001 and $514 \mathrm{~mm}$ in 2002. 
large woody roots were cut into $10 \mathrm{~cm}$ lengths and $1 \mathrm{~cm}$ portions were retained from each section; and 5 randomly selected clusters per vine were retained at fruit maturity. All of the fine roots, small woody roots, petioles, and flowers or fruit clusters (before maturity) were dried for further analysis.

All dried plant parts were ground to pass through a $40-$ mesh $(425-\mu \mathrm{m})$ screen and analyzed for nutrient concentrations by the Oregon State University, Central Analytical Lab. Nitrogen concentrations were determined by combustion analysis (CNS-2000 Macro Analyzer; Leco Inc., St. Louis, Mo.), and P, K, $\mathrm{Ca}, \mathrm{Mg}, \mathrm{Fe}, \mathrm{Mn}, \mathrm{B}, \mathrm{Cu}$, and $\mathrm{Zn}$ concentrations were measured by ICP-OES (Optima 3000DV; Perkin Elmer, Wellesley, Mass.) after dry-ashing samples (Jones and Case, 1990).
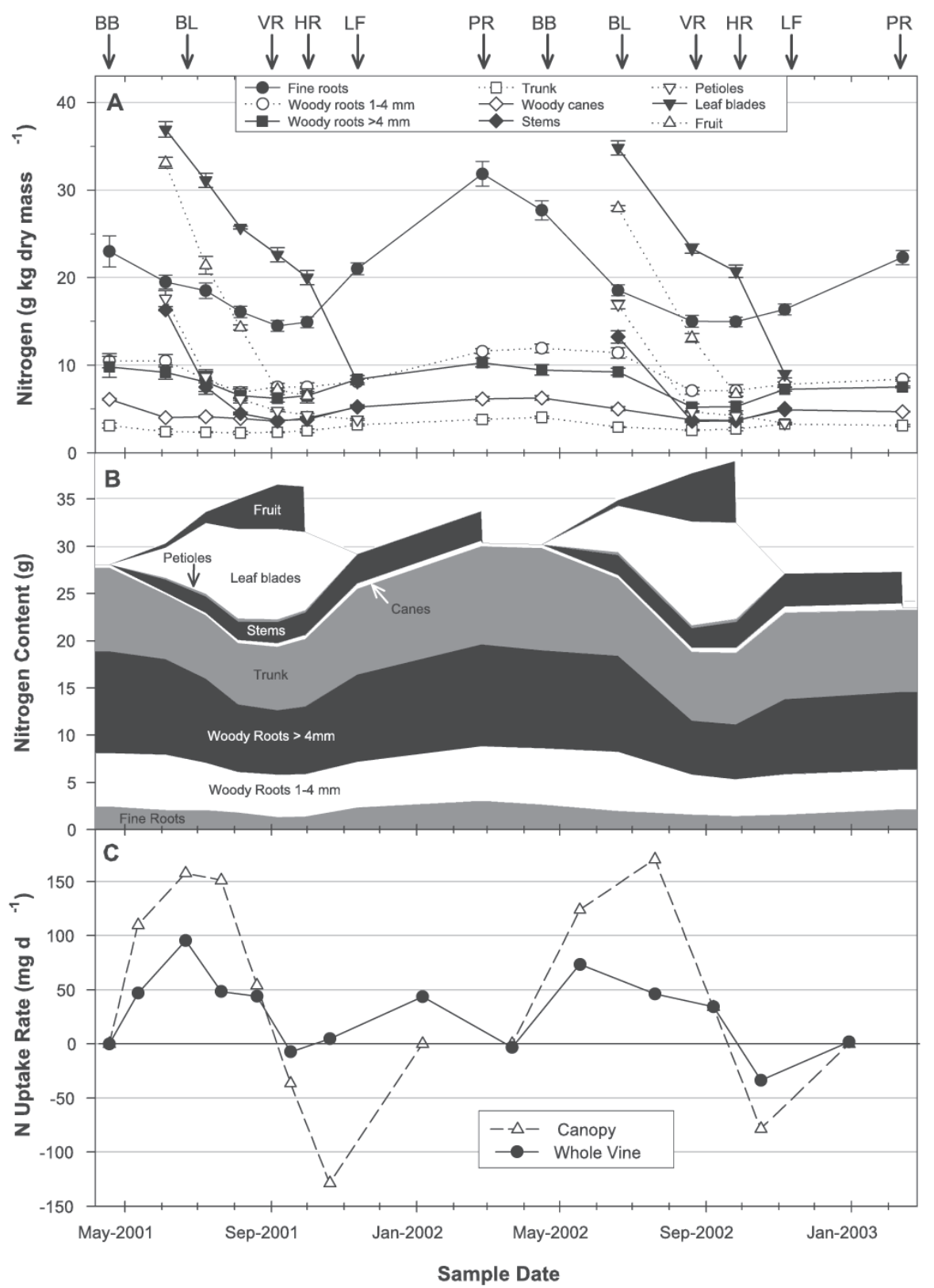

Fig. 4. Nitrogen concentrations (A), calculated contents (B), and canopy accumulation and whole vine uptake rates (C) of 'Pinot noir' grapevines in a western Oregon vineyard in 2001 and 2002. Data points in A represent means with standard errors at each sampling date $(n=4,2001 ; n=6,2002)$. Rates of accumulation and uptake $(\mathbf{C})$ are plotted as the midpoint between whole vine sampling dates. Arrows as in Fig. 2.
The average dry mass of plant parts removed from vines (stems, leaves, fruit) due to hedging, fruit thinning and leaf pulling were determined from the remaining vines to be sampled in each year. The contents of nutrients present in these removed plant parts were estimated by extrapolating from the concentrations of individual nutrients in the respective parts between whole vine sampling dates. The estimated content of each nutrient was then added to the respective content for a given plant part at subsequent sampling dates. Each vine sampled at leaf fall was enclosed in fine bird netting about 3 weeks after harvest (fruit maturity) to capture fallen leaf blades and petioles. Leaf blades and petioles were collected weekly until all leaves had fallen.

Randomly selected samples of five fruit .

$$
\text { in }
$$

\section{in} concentrations using standard procedures for western Oregon (Schreiner, 2005) by the Oregon State University, Central Analytical Lab. Soil test $\mathrm{NO}_{3}, \mathrm{NH}_{4}, \mathrm{P}, \mathrm{K}, \mathrm{Mg}, \mathrm{Ca}, \mathrm{Fe}, \mathrm{Zn}, \mathrm{Cu}$, $\mathrm{B}$, and $\mathrm{Mn}$ were determined.

Data analysis. Data were analyzed by ANOVA using type III sums of squares $(n=4$ in 2001 and $n=6$ in 2002) to examine changes in dry mass and nutrient concentrations of each plant part over time, and to compare variables at specific phenological stages between years, when possible (budbreak, veraison, harvest, leaf fall, pruning). Mean comparisons were conducted using Tukey's HSD method for unequal $\mathrm{n}$ at $95 \%$ confidence. The concentrations of macronutrients $(\mathrm{N}, \mathrm{P}, \mathrm{K}, \mathrm{Ca}$, and $\mathrm{Mg}$ ) in all plant parts varied significantly by sample date, except for fine root $\mathrm{Ca}$. The dry mass of fine roots, small woody roots, large woody roots and trunks did not vary significantly by sample date (Fig. 2B), so the mean values for dry mass across all sample dates were used with the mean values for nutrient concentrations at each sample date to calculate nutrient contents in these plant parts. Since neither fine root mass or fine root $\mathrm{Ca}$ concentrations changed over time, fine root $\mathrm{Ca}$ content was assumed to be constant. The dry mass of all other vine parts (canes, stems, leaf blades, petioles, clusters) changed significantly over time (Fig. 2A), so the mean values for dry mass and nutrient concentrations at each sampling date were used to calculate nutrient contents for all other plant parts.

Canopy uptake (demand) of each nutrient between sampling dates was calculated from the change in nutrient content of the stems + leaf blades + petioles + fruit clusters. Whole vine nutrient uptake from soil was determined from the change in total vine content of each nutrient between sampling dates. Rates for canopy demand and total vine uptake (as shown in panel $\mathrm{C}$ of Figs. 4 to 8 ) were calculated by dividing the change in content by the number of days between sampling dates. In calculating the canopy and whole vine uptake between harvest and leaf fall, the quantity of each nutrient still present in the fallen leaf blades and petioles was added to the canopy content or whole vine content at the leaf fall sampling. The contents of nutrients present in senescent 
leafblades and petioles are not shown in Figs. 4 to 8 (panel B), but concentrations in leafblades and petioles are shown (panel A) to highlight those nutrients that were remobilized from leaves before they were shed.

\section{Results}

\section{Weather and vine phenology}

In general, 2002 was warmer and drier than 2001 (Table 1, Fig. 3A). Warmer temperatures in April, June, and July of 2002 advanced budbreak by a few days and veraison by about 1 week compared to 2001. Bloom occurred a few days ahead in 2001, owing to a warmer May in that year. The date of harvest (fruit maturity) was only $3 \mathrm{~d}$ earlier in 2002, but if a more typical crop yield was carried on vines in 2001 harvest would likely have been much later. Rainfall during the growing season was greater in 2001 than 2002, both before harvest and between harvest and leaf fall (Fig. 3A). Even though more rain fell before budbreak in 2002, soil moisture was the same at the time of budbreak in both years. Lower rainfall and increased evapotranspiration resulted in lower available soil water in the latter part of the summer of 2002 compared to 2001.

\section{Soil nutrients}

Ammonium-N in soil was highest in the spring and decreased from budbreak through leaf fall, while nitrate $\mathrm{N}$ in soil increased from budbreak through leaf fall (Fig. 3B). Nitrate$\mathrm{N}$ also increased in soil in 2001 shortly after fertilizer application. There were no clear seasonal patterns in soil test values of other nutrients (data not shown). Mean values for

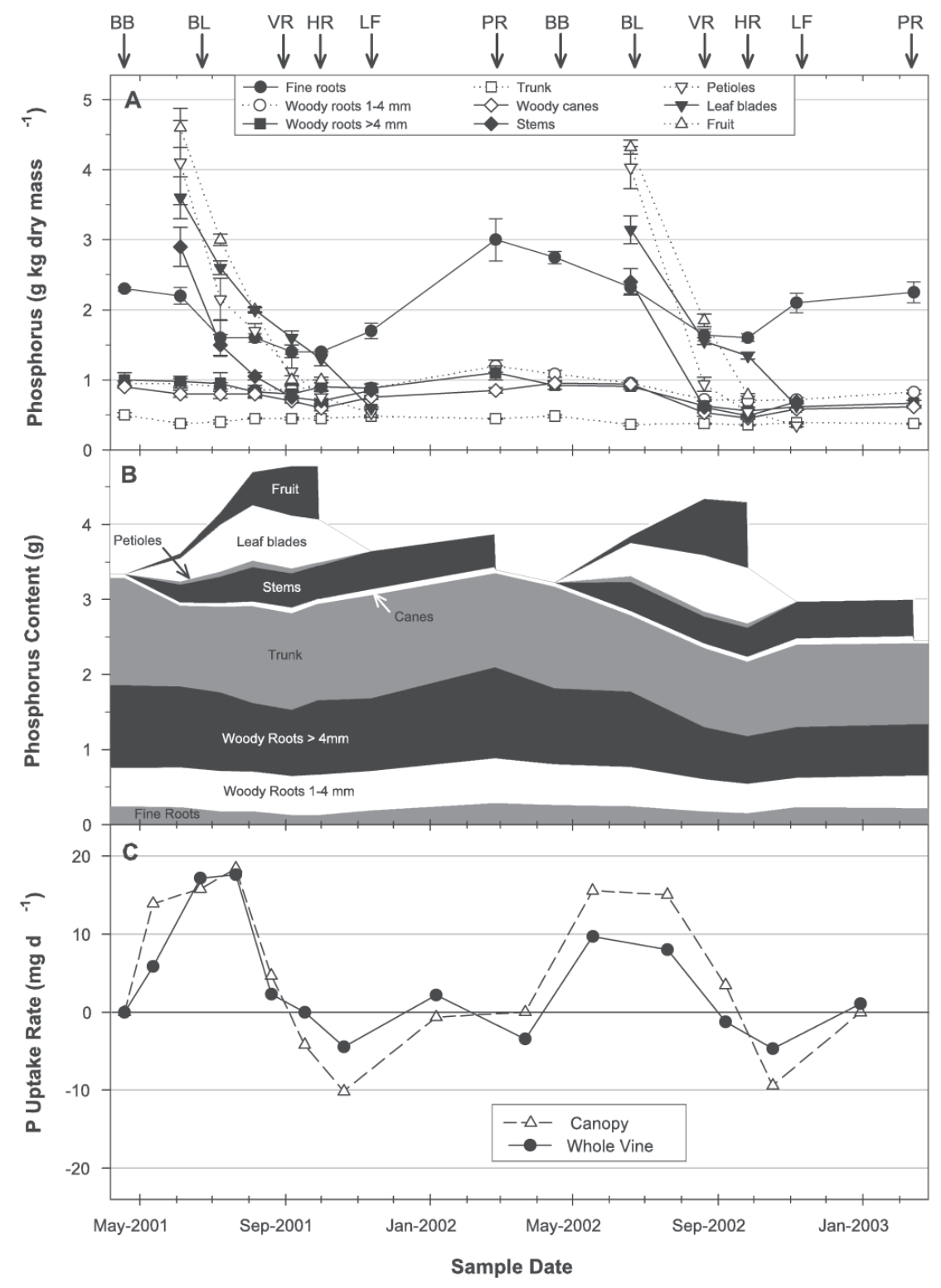

Fig. 5. Phosphorus concentrations (A), calculated contents (B), and canopy accumulation and whole vine uptake rates $(\mathbf{C})$ of 'Pinot noir' grapevines in a western Oregon vineyard in 2001 and 2002. Data points in (A) represent means with standard errors at each sampling date $(n=4,2001 ; n=6,2002)$. Rates of accumulation and uptake $(\mathbf{C})$ are plotted as the midpoint between whole vine sampling dates. Arrows as in Fig. 2. soil test nutrients (except $\mathrm{N}$ ) over all sampling dates were $11.0 \mathrm{mg} \cdot \mathrm{kg}^{-1} \mathrm{P}, 208 \mathrm{mg} \cdot \mathrm{kg}^{-1} \mathrm{~K}, 563$ $\mathrm{mg} \cdot \mathrm{kg}^{-1} \mathrm{Ca}, 73.1 \mathrm{mg} \cdot \mathrm{kg}^{-1} \mathrm{Mg}, 58.3 \mathrm{mg} \cdot \mathrm{kg}^{-1} \mathrm{Fe}$, $12.9 \mathrm{mg} \cdot \mathrm{kg}^{-1} \mathrm{Mn}, 0.60 \mathrm{mg} \cdot \mathrm{kg}^{-1} \mathrm{~B}, 0.75 \mathrm{mg} \cdot \mathrm{kg}^{-1}$ $\mathrm{Zn}$, and $0.91 \mathrm{mg} \cdot \mathrm{kg}^{-1} \mathrm{Cu}$.

\section{Vine growth and juice quality}

The dry mass of all 3 root fractions and trunks did not change significantly over the growing season (Fig. 2B). All remaining vine parts comprised of the above ground portions of vines showed significant changes in dry mass over time (Fig. 2A). The annual growth from canes, stems, leaf blades, petioles, and fruit accounted for $26 \%$ to $31 \%$ of total vine mass at harvest. Roots accounted for $25 \%$ of total vine dry mass at harvest in both years, and trunks accounted for $46 \%$ to $50 \%$ of total vine mass. The fine root fraction accounted for less than $2 \%$ of total vine dry matter. Differences in dry matter accumulation between years were found for fruit clusters and woody canes (Fig. 2A). Differences in the average yield of fresh grape clusters from the whole field in 2001 and 2002, 4050, and $5410 \mathrm{~kg} \cdot \mathrm{ha}^{-1}$, respectively, were due to different thinning practices. Cane mass was higher at fruit maturity, leaf fall, and pruning in 2002 compared to 2001. No other dry matter differences were significant at a specific growth stage between years. However, both the fruit and stem dry mass of vines increased significantly between veraison and harvest in 2002, but these changes were not significant in 2001. Juice quality factors were significantly different between years (Table 2). Pressed juice had more sugar and acids in 2002 than 2001, and a lower pH. In addition, whole cluster (including rachis and seeds) concentrations of $\mathrm{P}, \mathrm{K}, \mathrm{Ca}$, and $\mathrm{B}$ were significantly lower in 2002 (Table 2), indicating that juice concentrations of these nutrients were probably also lower.

Nitrogen. Changes in $\mathrm{N}$ concentrations of various vine parts were very similar in 2001 and 2002. N concentrations were highest and most dynamic in leaf blades and petioles, fruit clusters, stems, and fine roots of 'Pinot noir'. $\mathrm{N}$ concentrations in all vine organs were highest early in the growing season and declined throughout the summer, reaching the lowest values at veraison or harvest (roots, trunk, canes, stems and fruit) or at leaf fall (leaf blades and petioles, Fig. 4A). Between harvest and leaf fall, $\mathrm{N}$ concentrations in roots, trunk, canes, and stems increased while concentrations in petioles and leaf blades decreased. Between leaf fall and pruning, concentrations in roots, trunks, and woody canes continued to increase.

The highest rate of calculated $\mathrm{N}$ accumulation to the canopy occurred between bloom and veraison in both years, while the highest rate of calculated whole vine uptake was closer to bloom (Fig. 4C). A second peak of whole vine uptake occurred between leaf fall and pruning in 2001. Canopy demand for $\mathrm{N}$ exceeded plant uptake from budbreak through veraison and plant uptake exceeded canopy demand after harvest. A trend of greater canopy demand for $\mathrm{N}$ between budbreak and harvest in 2002, as compared to 2001, appeared to be met by 
greater remobilization of stored $\mathrm{N}$ in 2002 because uptake of $\mathrm{N}$ from soil was similar in both years (Table 3 ).

Phosphorus. Changes in the Pconcentrations of vine organs mirrored changes observed for $\mathrm{N}$ (Fig. 5A). While the changes in P concentrations of various vine parts were similar between years, lower P concentrations were found in canes, stems, petioles and fruit at veraison or harvest in 2002, as compared to 2001 (Fig. $5 \mathrm{~A})$. $\mathrm{P}$ concentrations were also highest and most dynamic in leaf blades and petioles, fruit clusters, stems and fine roots of vines.

Differences in seasonal changes of calculated $\mathrm{P}$ content between years showed much greater remobilization of root and trunk $\mathrm{P}$ to the canopy late in Summer 2002, compared to 2001 (Fig. 5B). At the end of 2002 there

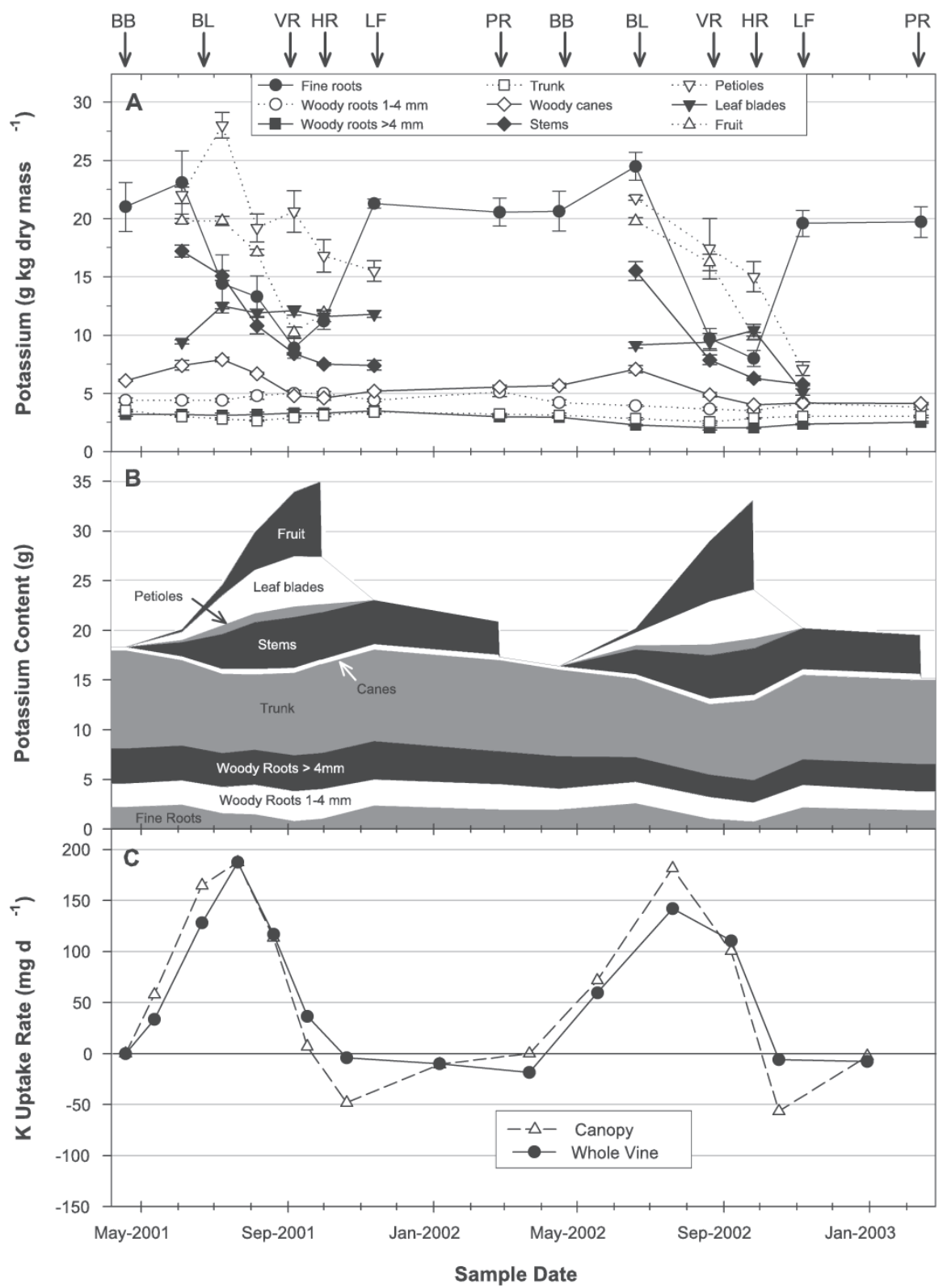

Fig. 6. Potassium concentrations (A), calculated contents (B), and canopy accumulation and whole vine uptake rates $(\mathbf{C})$ of 'Pinot noir' grapevines in a western Oregon vineyard in 2001 and 2002. Data points in (A) represent means with standard errors at each sampling date $(n=4,2001 ; n=6,2002)$. Rates of accumulation and uptake $(\mathbf{C})$ are plotted as the midpoint between whole vine sampling dates. Arrows as in Fig. 2. was about $0.6 \mathrm{~g}$ less $\mathrm{P}$ stored in the roots and trunks than at the end of 2001.

The highest rate of calculated $P$ accumulation in the canopy and of calculated whole vine uptake occurred between bloom and veraison in 2001, but the maximum rates of Pmovement appeared to occur before bloom in 2002 (Fig. 5C). Canopy demand for P exceeded plant uptake between budbreak and bloom in both years, but whole vine uptake closely matched canopy demand after bloom in 2001. Whole vine uptake rates of $\mathrm{P}$ fell short of canopy demand after bloom in 2002. The trend for greater canopy demand for $\mathrm{P}$ from budbreak to harvest in 2002, as compared to 2001, was met by greater remobilization of stored $\mathrm{P}$ in 2002 because soil uptake of $\mathrm{P}$ was lower in 2002 (Table 3, Fig. 5B).
Potassium. K concentration changes in various vine parts did not decline over each growing season as occurred with $\mathrm{N}$ and $\mathrm{P}$ (Fig. 6A). Leaf blade K concentrations increased up until harvest in both years, and fine root and cane $\mathrm{K}$ concentrations went up between budbreak and bloom before decreasing later in the summer in both years. Stem, petiole, and cluster K concentrations decreased throughout the growing season, but the relative decreases were not as large as for $\mathrm{N}$ and $\mathrm{P}$. $\mathrm{K}$ concentrations were significantly lower in large and small woody roots, canes, stems, leaf blades, petioles, and fruit clusters in the summer of 2002 compared to 2001 . Fine root $\mathrm{K}$ concentrations rebounded to high levels by the time of leaf fall in both years, which was faster than the increases in $\mathrm{N}$ and $\mathrm{P}$ in fine roots after harvest. Leaf blade and petiole $\mathrm{K}$ concentrations decreased significantly between harvest and leaf fall in 2002 , but not in 2001. K concentrations were highest and most dynamic in petioles, fruit clusters, stems and fine roots of vines.

Calculated $\mathrm{K}$ content in roots and trunks was lowest between veraison and harvest and highest between leaf fall and budbreak (Fig. 6B). Differences in seasonal changes in $\mathrm{K}$ content between 2001 and 2002 showed slightly more remobilization of root and trunk $\mathrm{K}$ to the canopy in late Summer 2002. At the end of 2002 there was about $1 \mathrm{~g}$ less $\mathrm{K}$ in storage than at the end of 2001 .

The highest rates of calculated $\mathrm{K}$ accumulation in the canopy and whole vines occurred between bloom and veraison in both years (Fig. 6C). While canopy demand for K exceeded plant uptake before about veraison in both years, canopy and whole vine uptake rates were more closely matched throughout the growing season than either $\mathrm{N}$ or $\mathrm{P}$ rates were. A trend of greater canopy demand for $\mathrm{K}$ between budbreak and harvest in 2002, as compared to 2001, also appeared to be met by greater remobilization of stored $\mathrm{K}$ in 2002 because uptake of $\mathrm{K}$ from soil was similar in both years (Table 3 ).

Calcium. Ca concentrations in leaf blades (both years) and petioles (2001) increased from bloom to leaf fall, but Ca concentrations in fruit decreased throughout the growing season in both years (Fig. 7A). Concentrations of $\mathrm{Ca}$ in other vine structures showed relatively minor changes throughout the two growing seasons. Changes in the calculated Ca contents of vine parts were similar in both years, although vines contained less total $\mathrm{Ca}$ in 2002, than in 2001(Fig. 7B). The highest rates of calculated Ca accumulation in the canopy and whole vines occurred between bloom and veraison in both years, and both uptake rates (canopy and whole vine) were closely matched (Fig. 7C).

Magnesium. $\mathrm{Mg}$ concentrations in vine parts were similar to changes found for $\mathrm{Ca}$. Concentrations of $\mathrm{Mg}$ in leaf blades and petioles increased throughout the growing season, and fruit $\mathrm{Mg}$ concentrations decreased in both years (Fig. 8A). Concentrations of $\mathrm{Mg}$ in other vine structures showed little change throughout the two growing seasons. Similar quantities of $\mathrm{Mg}$ were present in vines at the end of both years (Fig. 8B). The highest rates 
of calculated $\mathrm{Mg}$ accumulation in the canopy occurred between bloom and veraison in both years, but the calculated rate of whole vine uptake of $\mathrm{Mg}$ was greater after veraison in 2002 (Fig. 8C). Rates of canopy demand and whole vine uptake were also closely matched for $\mathrm{Mg}$. A trend of increased canopy demand for Mg in 2002, as compared to 2001, appeared to be met by increased uptake of $\mathrm{Mg}$ from soil (Table 3).

\section{Micronutrients}

The concentrations of micronutrients ( $\mathrm{Fe}$, $\mathrm{Mn}, \mathrm{Zn}, \mathrm{B}, \mathrm{Cu}$ ) within various vine parts changed significantly over time, except for small woody root $\mathrm{Mn}$, trunk $\mathrm{Zn}$ and $\mathrm{Cu}$, and stem $\mathrm{Mn}$ (data not shown). However, changes in the concentrations of micronutrients did not show clear seasonal trends. Of the micronutrients we measured, only calculated Mn contents increased $(P<0.05)$ in whole vines during the growing season in both years. The increase in vine Mn content was due to accumulation in the leaf blades, petioles, and stems, while no consistent patterns of accumulation occurred in the roots or trunks of vines (data not shown). Leaf blades contained the greatest quantity of Mn per vine (85 to $93 \mathrm{mg}$ at fruit maturity), while the highest concentrations of $\mathrm{Mn}$ occurred in petioles $\left(359 \mathrm{mg} \cdot \mathrm{kg}^{-1}\right.$ at leaf fall 2001$)$. The largest quantities of Fe were found in the small and large woody root fractions (about $300 \mathrm{mg}$ in each root fraction on average), and the greatest quantity of B (about $21 \mathrm{mg}$ ) or $\mathrm{Zn}$ (about $99 \mathrm{mg}$ ) was located in vine trunks. Fine roots contained the most $\mathrm{Cu}$, even though they

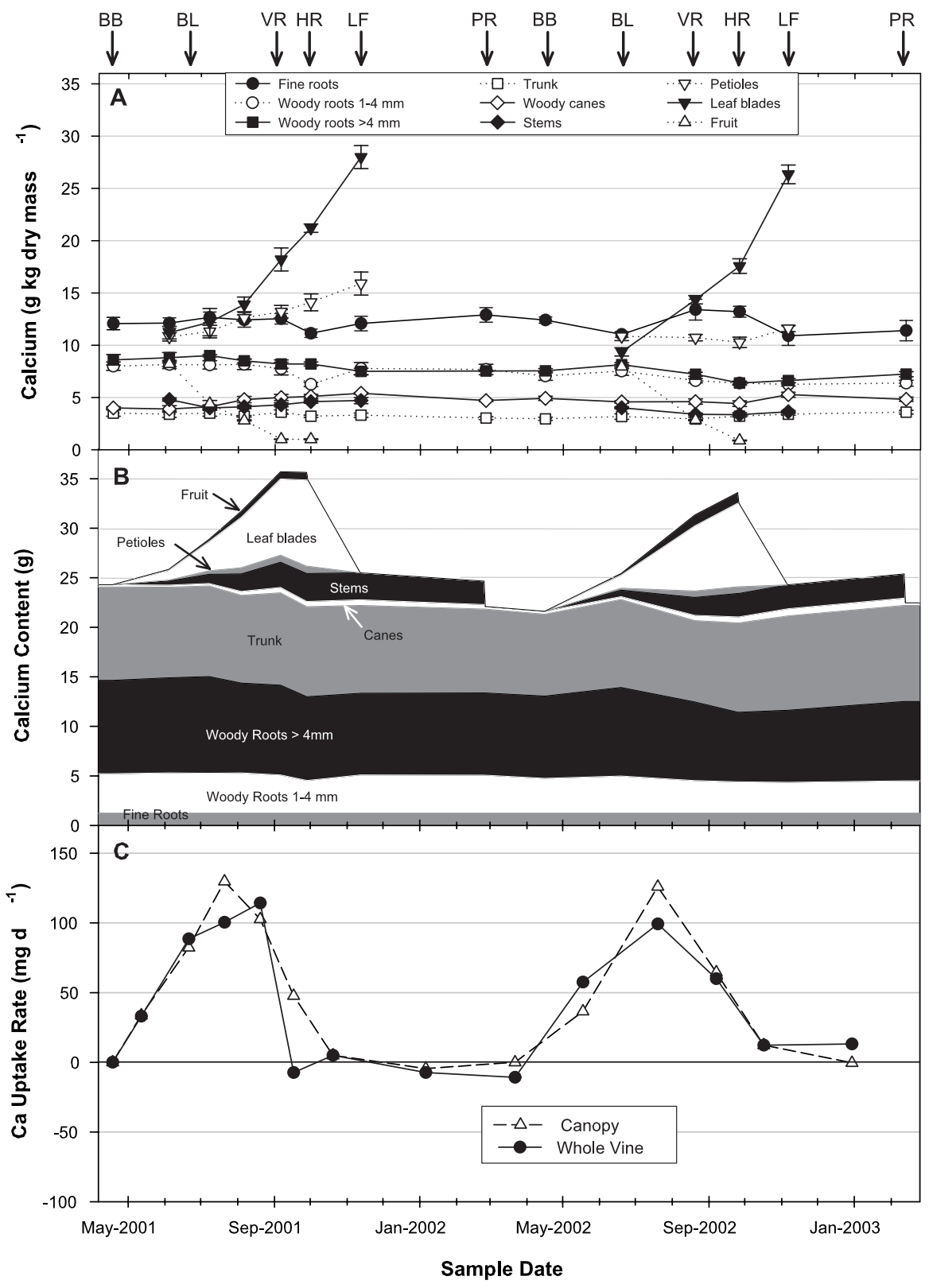

Fig. 7. Calcium concentrations (A), calculated contents (B), and canopy accumulation and whole vine uptake rates (C) of 'Pinot noir' grapevines in a western Oregon vineyard in 2001 and 2002. Data points in $\mathbf{A}$ represent means with standard errors at each sampling date $(n=4,2001 ; n=6,2002)$. Rates of accumulation and uptake $(\mathbf{C})$ are plotted as the midpoint between whole vine sampling dates. Arrows as in Fig. 2. only accounted for about $2 \%$ of vine mass. $\mathrm{Cu}$ concentrations in fine roots ranged from $86-349$ $\mathrm{mg} \cdot \mathrm{kg}^{-1}$, while concentrations in the rest of the vine were rarely above $10 \mathrm{mg} \cdot \mathrm{kg}^{-1}$.

\section{Discussion}

The overall patterns of dry matter accumulation and calculated nutrient $(\mathrm{N}, \mathrm{P}, \mathrm{K}$, $\mathrm{Ca}, \mathrm{Mg}$ ) uptake and distribution by mature, rainfed 'Pinot noir' grapevines were similar over two years in Oregon. However, differences between years that had occurred could be attributed to different crop levels and to different weather conditions in each year. Vines had a higher canopy demand for N, P, $\mathrm{K}$, and $\mathrm{Mg}$, which was associated with higher yield in 2002. Vines may have been exposed to greater water stress in 2002, based on greater evapotranspiration and lower soil moisture levels reached by late summer, as compared to 2001. These differences resulted in a trend for greater remobilization of $\mathrm{N}, \mathrm{K}$, and especially $\mathrm{P}$ from stored reserves in the trunk or roots in 2002 and to lower soil uptake of P in 2002, as compared to 2001. Our results for whole vine $\mathrm{P}, \mathrm{K}, \mathrm{Ca}$, and $\mathrm{Mg}$ requirements are the first to be reported for field-grown grapes over the whole year.

The seasonal patterns of macronutrient concentrations in 'Pinot noir' were similar in both years, even though $\mathrm{P}$ and $\mathrm{K}$ concentrations were lower in some tissues in 2002. Leaf blades, petioles, stems, and fruit clusters had high $\mathrm{N}$ concentrations early in the season and these declined throughout the summer. A large drop in the $\mathrm{N}$ concentration of senescent leaf blades showed that substantial remobilization of $\mathrm{N}$ occurred from leaf blades before leaf fall. These trends are consistent with the results from numerous studies (Araujo and Williams, 1988; Boselli et al., 1998, Colugnati et al., 1997; Conradie 1981b; Williams and Biscay, 1991).

Nitrogen concentrations in roots were high at budbreak, declined until veraison (2001) or harvest (2002), then increased between harvest and leaf fall in both years, and increased further between leaf fall and pruning in 2001. This data shows that substantial recharging of 'Pinot noir' $\mathrm{N}$ reserves in roots occurs after harvest, and may continue even after leaves are shed in the fall. $\mathrm{N}$ contents of the roots and trunk between leaf fall and pruning showed significant movement of $\mathrm{N}$ into these plant parts in 2001. Since the recapture of N from leaf blades and petioles was accounted for in our analysis, these changes reflect $\mathrm{N}$ uptake from soil. Continued uptake of $\mathrm{N}$ after leaf fall in 2001 was consistent with the high availability of nitrate in the soil at this time of year and favorable weather conditions. This is the first report of $\mathrm{N}$ uptake in grapevines after leaf fall. Conradie (1980) also found significant $\mathrm{N}$ uptake between harvest and leaf fall, but no further uptake after leaf fall. However, the period between harvest and leaf fall was much longer than in our study and vines received water and fertilizer during this time. Others have found the lowest root $\mathrm{N}$ concentrations or contents of grapevines to occur at veraison 
(Hanson and Howell, 1995; Mullins et al., 1992; Williams and Biscay, 1991) or harvest (Araujo and Williams, 1988; Bates et al., 2002; Conradie, 1980) with increases occurring by the time of leaf fall. Bates et al. (2002), who separated roots into fine and woody fractions, just as we did, found that $\mathrm{N}$ concentrations in fine roots increased from budbreak to bloom, which is in contrast to our results. However, fine $\operatorname{root} \mathrm{N}$ concentrations of the vines studied by Bates et al. (2002) were only about $50 \%$ of the values we found. These differences are most likely due to the large differences in vine age between the two studies.

Changes in $\mathrm{N}$ content within the canopy of 'Pinot noir' showed that leaf blades were the most important sink for $\mathrm{N}$ accumulation, as observed previously (Conradie, 1980; Williams,
1987). Both $\mathrm{N}$ uptake from soil and remobilization of stored $\mathrm{N}$ were needed to supply the developing canopy in our vines. The largest fraction of stored $\mathrm{N}$ used to support canopy development came from large woody roots, followed by the trunk. Others have found that $\mathrm{N}$ was primarily used from the trunk, followed by the large woody roots (Conradie, 1980; Löhnertz, 1991). In our study, about $50 \%$ of canopy demand for $\mathrm{N}$ by harvest was supplied from stored $\mathrm{N}$ reserves. This value is higher than previous reports (Bates et al., 2002; Conradie, 1980; Hanson and Howell, 1995; Williams, 1991). We also found that remobilization of $\mathrm{N}$ from the roots and trunk to the canopy of 'Pinot noir' was more pronounced after bloom than before bloom, which is the opposite of previous reports (Conradie, 1980; Löhnertz
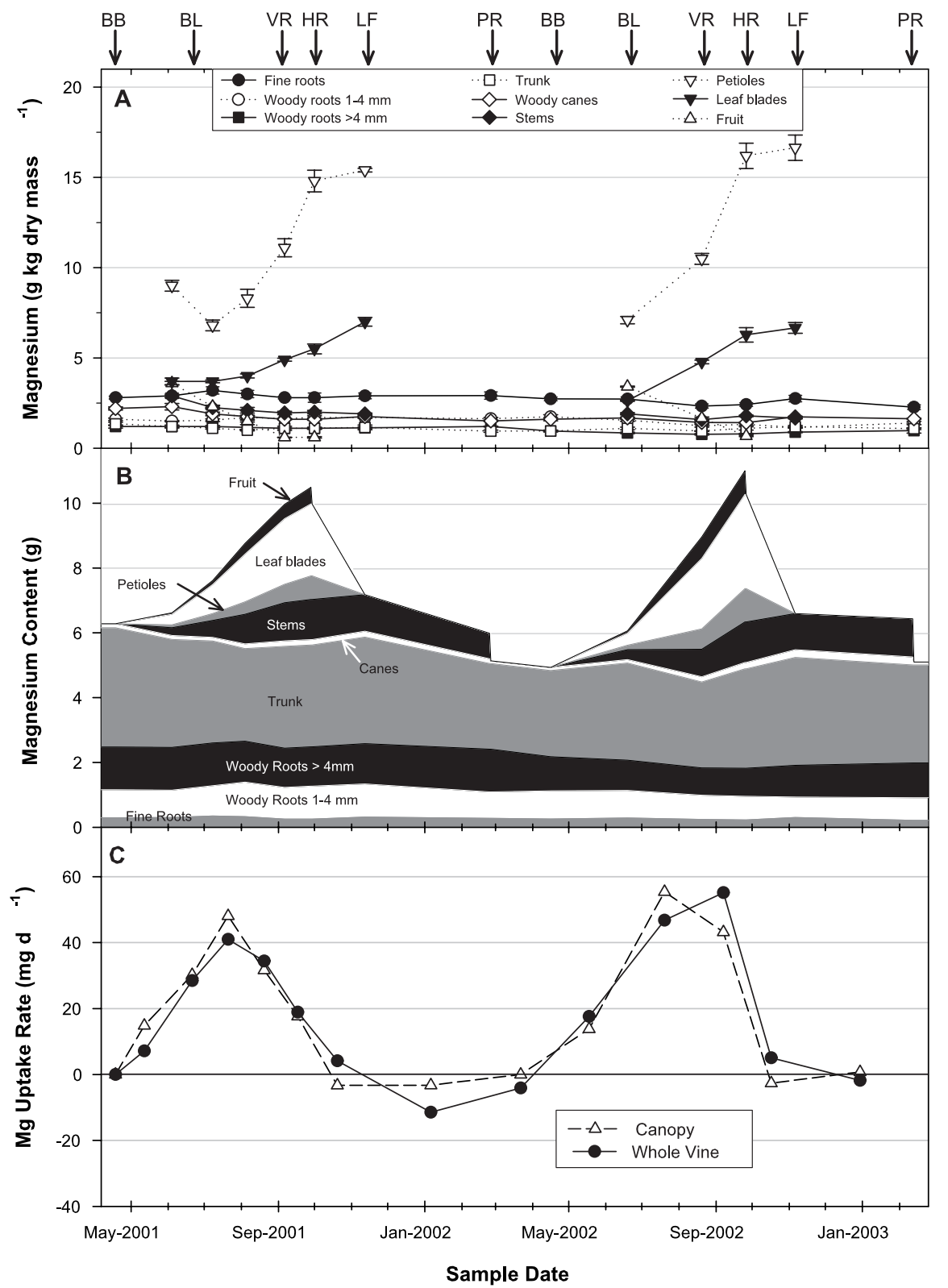

Fig. 8. Magnesium concentrations (A), calculated contents (B), and canopy accumulation and whole vine uptake rates $(\mathbf{C})$ of 'Pinot noir' grapevines in a western Oregon vineyard in 2001 and 2002. Data points in $\mathbf{A}$ represent means with standard errors at each sampling date $(n=4,2001 ; n=6,2002)$. Rates of accumulation and uptake $(\mathbf{C})$ are plotted as the midpoint between whole vine sampling dates. Arrows as in Fig. 2.
1991). This finding suggests that rainfed vines continue to rely on stored reserves later in the summer than irrigated vines. This is supported by our results showing more of the canopy $\mathrm{N}$ was supplied from reserves in the drier 2002 growing season.

Phosphorus concentrations of 'Pinot noir' showed similar seasonal trends between years as $\mathrm{N}$ concentrations. Our values for leaf blade and petiole $\mathrm{P}$ concentrations were much lower than those found in 2-year-old 'Chenin blanc' vines studied by Conradie (1981b) and in a California survey of winegrape varieties (Christensen, 1984). However, our bloom values were higher than those reported for winegrapes in Europe (Boselli et al., 1998, Colugnati et al., 1997). The ratio of petiole $P$ to leaf blade $\mathrm{P}$ concentrations has been suggested as a good indicator of $P$ status, because $\mathrm{P}$ accumulates in the petiole when supply is adequate (Cook, 1966). A petiole to leaf blade $\mathrm{P}$ concentration ratio below 0.6 at the time of harvest has been suggested to indicate P deficiency in winegrapes (Klein et al., 2000). Our petiole:leaf blade $\mathrm{P}$ concentration ratio at harvest was 0.58 in 2001 and 0.40 in 2002, which is consistent with the low P-status of this vineyard (Schreiner, 2005). Even lower $\mathrm{P}$ concentrations have been found in Oregon winegrapes (Schreiner and Linderman, 2005), suggesting that vineyards in Oregon may be limited by $\mathrm{P}$.

We found that most of the P required by the canopy of 'Pinot noir' came from soil uptake in 2001 (about 20\% came from reserves), while only half of canopy P came from soil uptake in 2002. Less $P$ was taken up from soil in 2002 probably due to the drier soil conditions. No difference in the level of root colonization by arbuscular mycorrhizal fungi was found between years (data not shown) and fine root mass was also not different between years. It seems, therefore, that the potential for root absorption of $\mathrm{P}$ was similar in both years, but the drier conditions in 2002 reduced actual $\mathrm{P}$ uptake in that year. $\mathrm{P}$ that was remobilized to the canopy from stored reserves came predominantly from the large woody roots. Conradie (1981a) found little remobilization of $\mathrm{P}$ from roots to support canopy demand, most likely because $\mathrm{P}$ was in relatively high supply in that study and vines were much younger than ours.

The strong demand of fruit clusters for $\mathrm{K}$ was evident in our vines, as observed in previous studies (Conradie, 1981a; Possner and Kliewer, 1985; Williams and Biscay, 1991; Williams et al., 1987). Even with the heavy fruit thinning conducted in 2001 , K contents in developing clusters increased substantially until harvest. The movement of $\mathrm{K}$ into the fruit was maintained at a high rate from bloom up until harvest. In comparison, the movement of other macroelements to the clusters began to slow down after veraison, as observed in prior studies (Conradie, 1980; 1981a; Possner and Kliewer, 1985). Managing vines for low crop levels is a standard practice for production of winegrapes in Oregon. This practice may increase the probability of an oversupply of $\mathrm{K}$ resulting in high juice $\mathrm{pH}$ for grapes grown in this region. The concentration of soil test 
Table 2. Vine growth, juice characteristics, and cluster (including rachis) nutrients of 'Pinot noir' grapevines in 2001 and 2002.

\begin{tabular}{|c|c|c|c|c|}
\hline Parameter & & 2001 & 2002 & $P^{z}$ \\
\hline \multirow[t]{3}{*}{ Dry mass } & Stems (g/vine) & $613(97)^{y}$ & $703(55)$ & NS \\
\hline & Leaf blades (g/vine) & $404(45)$ & $435(25)$ & NS \\
\hline & Fruit $(\mathrm{g} / \mathrm{vine})$ & 385 (17) & $638(26)$ & $<0.001$ \\
\hline \multirow{13}{*}{ Fruit quality } & Soluble solids $\left({ }^{\circ} \mathrm{Brix}\right)$ & $23.4(0.22)$ & $25.1(0.43)$ & 0.013 \\
\hline & $\mathrm{pH}$ & $3.78(0.03)$ & $3.31(0.02)$ & $<0.001$ \\
\hline & Titratable acidity $\left(\mathrm{g} \cdot \mathrm{L}^{-1}\right)$ & $5.81(0.10)$ & $7.84(0.17)$ & $<0.001$ \\
\hline & Cluster $\mathrm{N}\left(\mathrm{g} \cdot \mathrm{kg}^{-1}\right)$ & $6.50(0.30)$ & $6.68(0.18)$ & NS \\
\hline & Cluster $\mathrm{P}\left(\mathrm{g} \cdot \mathrm{kg}^{-1}\right)$ & $1.09(0.04)$ & $0.78(0.02)$ & $<0.001$ \\
\hline & Cluster $K\left(\mathrm{~g} \cdot \mathrm{kg}^{-1}\right)$ & $11.8(0.27)$ & $10.1(0.28)$ & 0.003 \\
\hline & Cluster $\mathrm{Ca}\left(\mathrm{g} \cdot \mathrm{kg}^{-1}\right)$ & $1.11(0.04)$ & $0.88(0.04)$ & 0.006 \\
\hline & Cluster $\mathrm{Mg}\left(\mathrm{g} \cdot \mathrm{kg}^{-1}\right)$ & $0.72(0.05)$ & $0.68(0.04)$ & NS \\
\hline & Cluster $\mathrm{Fe}\left(\mathrm{mg}^{\circ} \mathrm{kg}^{-1}\right)$ & $36.5(0.64)$ & $36.6(1.44)$ & NS \\
\hline & Cluster Mn $\left(\mathrm{mg} \cdot \mathrm{kg}^{-1}\right)$ & $14.2(1.69)$ & $12.9(1.18)$ & NS \\
\hline & Cluster B $\left(\mathrm{mg} \cdot \mathrm{kg}^{-1}\right)$ & $14.7(0.76)$ & $8.6(0.54)$ & $<0.001$ \\
\hline & Cluster $\mathrm{Zn}\left(\mathrm{mg} \cdot \mathrm{kg}^{-1}\right)$ & $4.0(0.30)$ & $4.3(0.11)$ & NS \\
\hline & Cluster $\mathrm{Cu}\left(\mathrm{mg} \cdot \mathrm{kg}^{-1}\right)$ & $4.0(0.18)$ & $4.7(0.27)$ & NS \\
\hline
\end{tabular}

${ }^{\mathrm{z}}$ Values from ANOVA comparing differences between years.

${ }^{y}$ Standard error of mean $(n=4$ in 2001, $n=6$ in 2002).

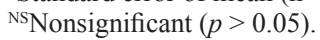

Table 3. Summary of calculated nutrient uptake and distribution $\left(\mathrm{kg} \cdot \mathrm{ha}^{-1}\right)$ for 'Pinot noir' grapevines between budbreak and harvest in 2001 and 2002.

\begin{tabular}{|c|c|c|c|c|c|c|}
\hline \multirow[b]{2}{*}{ Nutrient } & \multicolumn{2}{|c|}{$\begin{array}{l}\text { Canopy } \\
\text { demand }\end{array}$} & \multicolumn{2}{|c|}{$\begin{array}{l}\text { Uptake } \\
\text { from soil }\end{array}$} & \multicolumn{2}{|c|}{$\begin{array}{l}\text { Remobilization } \\
\text { from reserves }\end{array}$} \\
\hline & 2001 & 2002 & 2001 & 2002 & 2001 & 2002 \\
\hline$\overline{\mathrm{N}}$ & 32.4 & 39.5 & 16.9 & 17.7 & 15.6 & 21.8 \\
\hline $\mathrm{P}$ & 3.66 & 4.10 & 2.88 & 2.14 & 0.78 & 1.96 \\
\hline $\mathrm{K}$ & 35.8 & 39.1 & 33.3 & 33.4 & 2.50 & 5.76 \\
\hline $\mathrm{Ca}$ & 25.8 & 25.1 & 23.1 & 24.1 & 2.76 & 0.96 \\
\hline $\mathrm{Mg}$ & 9.40 & 11.8 & 8.42 & 12.1 & 0.98 & 0 \\
\hline
\end{tabular}

$\mathrm{K}\left(208 \mathrm{mg} \cdot \mathrm{kg}^{-1}\right)$ appeared to be sufficient for older vines producing about $5500 \mathrm{~kg} \cdot \mathrm{ha}^{-1}$ of grapes (2002), but was excessive for vines producing about $4000 \mathrm{~kg} \cdot \mathrm{ha}^{-1}(2001)$.

Very little $\mathrm{K}$ was remobilized to the developing canopy of 'Pinot noir' from stored reserves in the trunk or roots in 2001 , but more of canopy K came from stored reserves in 2002. Overall, canopy demand and whole vine uptake rates for $\mathrm{K}$ were similar, indicating that most of vine $\mathrm{K}$ was supplied from soil uptake. We saw no evidence of remobilization of $\mathrm{K}$ from the leaves or stems to support cluster demand late in the season, as observed by others (Conradie 1981a; Williams and Biscay, 1991). The trunk and fine roots were the most important plant parts in supplying the small quantity of $\mathrm{K}$ that was remobilized from stored reserves to the canopy.

Leaf blade and petiole $\mathrm{Ca}$ concentrations that we observed in 'Pinot noir' were lower than previous studies for field grown grapes in California (Christensen 1969, Cook and Lider, 1964) or southern Italy (Boselli etal., 1998) and slightly lower than the values for potted 'Chenin blanc' vines studied by Conradie (1981b). Our $\mathrm{Mg}$ concentrations in leaf blades and petioles were higher than most values reported in the literature (Boselli et al., 1998; Conradie 1981b; Colugnati et al., 1997; Cook and Lider, 1964), which is probably a result of the ample supply of $\mathrm{Mg}$ in our soil. Ca and $\mathrm{Mg}$ concentrations in leaf blades and petioles of 'Pinot noir' were above critical concentrations and fell within adequate concentration ranges reported for grapevines (Bergman et al. 1960; Cook 1966; Gärtel, 1996; Robinson, 1992; Scott and Scott, 1952; Skinner and Matthews, 1990, Wolf et al., 1983).
Calcium and $\mathrm{Mg}$ accumulated primarily in the leaf blades over the growing season, although $\mathrm{Mg}$ also accumulated in petioles. This difference is likely due to the low phloem mobility of Ca versus Mg (Marschner, 1995). Neither element was remobilized from senescent leaves before leaf fall. These findings are similar to those of Conradie (1981a) for potted 'Chenin blanc' vines. At harvest, clusters contained very small amounts of $\mathrm{Ca}$ and $\mathrm{Mg}$ in relation to other vine structures. $\mathrm{Ca}$ and $\mathrm{Mg}$ supplied to the canopy came largely from soil uptake with essentially none coming from stored reserves. There was greater Mg uptake from soil in 2002 compared to 2001, probably indicating that vines obtained more water from deeper soil layers in the drier 2002 season. The subsoil ( $\mathrm{B}$ and $\mathrm{C}$ horizons) at this site contains significantly higher $\mathrm{Mg}$ concentrations than the topsoil (Schreiner, 2005).

The vines we studied had a much larger proportion of dry mass present in the root and trunk fractions, nearly $75 \%$ of vine dry matter, as compared to previous whole vine studies, which reported $<40 \%$ (Araujo and Williams, 1988; Bates et al., 2002; Conradie, 1980; Hanson and Howell, 1995; Mullins et al., 1992; Williams, 1991). Only Williams and Biscay (1991) found a similar, large proportion of vine mass in the roots and trunk (64\%) in rainfed, 18 year-old 'Cabernet Sauvignon' vines. It is tempting to conclude that nonirrigated vines direct greater resources to roots, however, both our vines and the vines studied by Williams and Biscay (1991) were older than vines from the other studies.

While others have shown increases in trunk and root mass of young grapevines during the growing season (Araujo and Williams, 1988; Bates et al., 2002; Conradie, 1980), we did not find a significant increase in the mass of these tissues in 'Pinot noir'. Our results are similar to findings by Hanson and Howell (1995) in 10 -year-old Concord vines.

Roots were sampled differently in 2002 than in 2001 because we were concerned that the soil block approach used in 2001 may have underestimated the quantity of large woody roots. However, both approaches gave similar quantities of roots. This suggests that the average values for each root class across all sampling dates is a robust estimate of root dry mass of the 'Pinot noir' vines in this vineyard. The lack of change in fine root mass throughout the summer in this study is similar to previous findings based on root length in the same vineyard (Schreiner, 2005).

In 2002, when fruit was thinned only once, there was a large accumulation of cluster dry mass between veraison and harvest. A similar pattern of cluster dry mass accumulation has been observed by others in vines with fruit clusters accounting for $19 \%$ to $49 \%$ of total vine dry mass (Araujo and Williams, 1988; Bates et al., 2002; Conradie, 1980; 1986; Hanson and Howell, 1995; Mullins et al., 1992; Williams and Biscay, 1991). The vines we studied had a smaller crop level than previous studies with fruit clusters comprising only $10 \%$ of total vine dry mass.

The quantities of $\mathrm{N}, \mathrm{P}, \mathrm{K}, \mathrm{Ca}$, and $\mathrm{Mg}$ that left the vineyard system with harvested fruit in 2002 were $8.3,1.0,12.5,1.1$, and 0.8 $\mathrm{kg} \cdot \mathrm{ha}^{-1}$, respectively. The yield in $2002(5400$ $\mathrm{kg} \cdot \mathrm{ha}^{-1}$ ) was more typical for this site. The amounts of $\mathrm{N}, \mathrm{K}, \mathrm{Ca}$, and $\mathrm{Mg}$ removed from the vineyard per ton of fruit were similar to values reported in prior studies, but the $\mathrm{P}$ in our 'Pinot noir' grapes was lower than previous reports (summarized by Mullins et al., 1992). The low $\mathrm{P}$ in fruit clusters at harvest support our leaf and root data in suggesting that $\mathrm{P}$ is a limiting nutrient in this vineyard. The quantities of $\mathrm{N}, \mathrm{P}, \mathrm{K}, \mathrm{Ca}$, and $\mathrm{Mg}$ required to produce a typical 'Pinot noir' crop (e.g., 2002) at this site are lower than most agricultural crops. In fact, our $\mathrm{N}$ requirement is lower than any other published field studies on grapevines (Araujo and Williams, 1988; Bates et al., 2002, Hanson and Howell, 1995; Löhnertz, 1991; Williams, 1991; Williams and Biscay, 1991). We think this is largely due to the much older vines we studied, which have a greater capacity for $\mathrm{N}$ (and P) storage in trunks and large woody roots, but is also related to the low crop level of our vines.

\section{Conclusions}

New canopy growth of mature 'Pinot noir' grapevines grown without irrigation in a red hill soil in Oregon required about $40 \mathrm{~kg} \cdot \mathrm{ha}^{-1}$ of $\mathrm{N}$ or $\mathrm{K}, 4 \mathrm{~kg} \cdot \mathrm{ha}^{-1}$ of $\mathrm{P}, 25 \mathrm{~kg} \cdot \mathrm{ha}^{-1}$ of $\mathrm{Ca}$, and $10 \mathrm{~kg} \cdot \mathrm{ha}^{-1}$ of $\mathrm{Mg}$. However, as much as $50 \%$ of the $\mathrm{N}$ or P required by the developing canopy was supplied from stored reserves in the trunk and roots, while $<15 \%$ of $\mathrm{K}$ and $10 \%$ of $\mathrm{Ca}$ or $\mathrm{Mg}$ came from stored reserves. During drier years a greater percentage of canopy 
requirements for $\mathrm{N}, \mathrm{K}$, and especially $\mathrm{P}$ may come from reserves. This could result in a depletion of these nutrients over a number of consecutive dry years indicating that irrigation may be beneficial at this site. Maximal rates of $\mathrm{N}$ and $\mathrm{P}$ uptake from soil by 'Pinot noir' occurred about the time of flowering when substantial remobilization from reserves was also occurring. Maximal rates for vine $\mathrm{K}, \mathrm{Ca}$, and $\mathrm{Mg}$ uptake occurred between bloom and veraison. The postharvest period is an important time for vines to replenish reserves of $\mathrm{N}$, $\mathrm{P}$ and $\mathrm{K}$ in Oregon.

\section{Literature Cited}

Anderson, L.J., L.H. Comas, A.N. Lakso, and D.M Eissenstat. 2003. Multiple risk factors in root survivorship: A 4-year study in Concord grape. New Phytol. 158:489-501.

Araujo, F.J. and L.E Williams. 1988. Dry matter and nitrogen partitioning and root growth of young field-grown Thompson Seedless grapevines. Vitis 27:21-32.

Bates, T.R., R.M. Dunst, and P. Joy. 2002. Seasonal dry matter, starch, and nutrient distribution in 'Concord' grapevine roots. HortScience 37:313-316.

Bergman, E.L., A.L. Kenworthy, S.T Bass, and E.J. Benne.1960. Growth of Concord grapes in sand cultures as related to various levels of essential nutrient elements. Proc. Amer. Soc. Hort. Sci. 75:329-340.

Boselli, M., C. Di Vaio, and R. Pica. 1998. Effect of soil moisture and transpiration on mineral content in leaves and berries of Cabernet Sauvignon grapevine. J. Plant Nutr. 21:1163-1178.

Christensen, P. 1969. Seasonal changes and distribution of nutritional elements in Thompson Seedless grapevines. Amer. J. Enol. Viticult. 20:176-190.

Christensen, P. 1984. Nutrient level comparisons of leaf petioles and blades in twenty-six grape cultivars over three years (1979 through 1981). Amer. J. Enol. Viticult. 35:124-133.

Colugnati, G., A. Boschin, F. Bregant, S. Tagliavini, and M. Montanari. 1997. Preliminary results concerning the effects of a new fertilizer for grape nutrition. Acta. Hort. 448:403-410.

Conradie, W.J. 1980. Seasonal uptake of nutrients by Chenin blanc in sand culture: I nitrogen. S. Afr. J. Enol. Viticult. 1:59-65.

Conradie, W.J. 1981a. Seasonal uptake of nutrients by Chenin blanc in sand culture. II. Phosphorus, potassium, calcium and magnesium. S. Afr. J. Enol. Viticult. 2:7-13.

Conradie, W.J. 1981b. Nutrient consumption by Chenin blanc grown in sand culture and seasonal changes in the chemical composition of leaf blades and petioles. S. Afr. J. Enol. Viticult. 2:15-18.

Conradie, W.J. 1986. Utilization of nitrogen by the grape-vine as affected by time of application and soil type. S. Afr. J. Enol. Viticult. 7:76-83.

Conradie, W.J.2005. Partitioning of mineral nutrients and timing of fertilizer applications for optimum efficiency, p. 69-81. In: L.PChristensen and D.R Smart (eds.). Proceedings of the soil environment and vine mineral nutrition symposium. Amer. Soc. Enol. Viticult., Davis, Calif.

Cook, J.A. 1966. Grape nutrition, p. 777-812. In N.F. Childers (ed.). Nutrition of fruit crops. Somerset Press, Somerville, N.J.

Cook, J.A. and L.A. Lider. 1964. Mineral composition of bloomtime grape petiole in relation to rootstock and scion variety behavior. Proc. Amer. Soc. Hort Sci. 84:243-254.

Freeman, B.M. and R.E. Smart. 1976. Aroot observation laboratory for studies with grapevines. Am. J. Enol. Vitic. 27:36-39.

Gardner, W.H. 1986. Water content, p. 493-544. In: A. Klute (ed.). Methods of soil analysis. Part 1 Physical and mineralogical methods. Amer. Soc. Agron., Madison, Wis.

Gärtel, W. 1996. Grapes, pp. 177-183. In: W.F. Bennett (ed.). Nutrient deficiencies and toxicities in crop plants. APS Press, St Paul, Minn.

Hanson, E.J. and G.S. Howell. 1995. Nitrogen accumulation and fertilizer use efficiency by grapevines in short-season growing areas. HortScience 30:504-507.

Jones, J. B. and V. W. Case. 1990. Sampling, handling, and analyzing plant tissue samples, p. 389-427. In: R.L. Westerman (ed.). Soil testing and plant analysis. 3rd ed.Soil Sci. Soc. Amer. Madison, Wis.

Klein, I., M. Strime, L. Fanberstein, and Y. Mani. 2000. Irrigation and fertigation effects on phosphorus and potassium nutrition of wine grapes. Vitis 39:55-62.

Löhnertz, O. 1991. Soil nitrogen and the uptake of nitrogen in grapevines, p. 1-11. In: J.M. Rantz (ed.). Proceedings of the International Symposium on Nitrogen in Grapes and Wine. Amer. Soc. Enol. Viticult., Davis, Calif.

Marschner, H. 1995. Mineral nutrition of higher plants. 2nd ed. Academic Press, San Diego, Calif.

Mullins, M.G., A. Bouquet, and L.E. Williams. 1992. Biology of the Grapevine. Cambridge Univ. Press, Cambridge.

Peacock, W.L., L.P. Christensen, and F.E. Broadbent. 1989. Uptake, storage, and utilization of soil-applied nitrogen by Thompson Seedless as affected by time of application. Amer. J. Enol. Viticult. 40:16-20.

Perret, P., P. Weissenbach, H. Schwager, W.E. Heller, and W. Koblet. 1993. Adaptive nitrogen-management $-\mathrm{A}$ tool for the optimization of N-fertilization in vineyards. Viticult. Enol. Sci. 48:124-126.

Possner, D.R.E. and W.M. Kliewer. 1985. The localization of acids, sugars, potassium and calcium in developing grape berries. Vitis 24:229-240.

Robinson, J.B. 1992. Grapevine nutrition, p. 178-208. In: B.G. Coombe and P.R. Dry (eds.). Viticulture. vol. 2. Practices. Winetitles, Adelaide.

Schreiner, R.P. 2003. Mycorrhizal colonization of grapevine rootstocks under field conditions. Am. J. Enol. Viticult. 54:143-149.

Schreiner, R.P. 2005. Spatial and temporal variation of roots, arbuscular mycorrhizal fungi, and plant and soil nutrients in a mature Pinot noir (Vitis vinifera L.) vineyard in Oregon, USA. Plant Soil 276:219-234.

Schreiner, R.P. and R.G. Linderman. 2005. Mycorrhizal colonization in dryland vineyards of the Willamette Valley, Oregon. Small Fruits Rev. 4:41-55.

Scott, L.E. and D.H. Scott. 1952. Further observations on the response of grape vines to soil and spray applications of magnesium sulfate. Proc. Amer. Soc. Hort. Sci. 60:117-122.

Skinner, P.W. and M.A. Matthews. 1990. A novel interaction of magnesium translocation with the supply of phosphorus to roots of grapevine (Vitis vinifera L.). Plant Cell Environ. 13:821-826.

Van Zyl, J.L. 1988. The grapevine root and its environment. Dept. Agr. Water Supply, Pretoria, S. Afr.

Vos, R.J., T.J.Zabadal, and E.J. Hanson. 2004. Effect of nitrogen application timing on $\mathrm{N}$ uptake by Vitis labrusca in a short-season region. Amer. J. Enol. Viticult. 55:246-252.

Williams, L.E. 1987. Growth of 'Thompson Seedless' grapevines: II. Nitrogen distribution. J. Amer. Soc. Hort. Sci. 112:330-333.

Williams, L.E. 1991. Vine nitrogen requirementsUtilization of $\mathrm{N}$ sources from soils, fertilizers, and reserves, p. 62-66. In: J.M. Rantz (ed.). Proceedings of the International Symposium on Nitrogen in Grapes and Wine. Amer. Soc. Enol. Viticult., Davis, Calif.

Williams, L.E. and P.J. Biscay. 1991. Partitioning of dry weight, nitrogen, and potassium in Cabernet Sauvignon grapevines from anthesis until harvest. Amer. J. Enol. Viticult. 42:113-117.

Williams, L.E., P.J. Biscay, and R.J. Smith.1987. Effect of interior canopy defoliation on berry composition and potassium distribution in Thompson Seedless grapevines. Amer. J. Enol. Viticult. 38:287-292.

Wolf, T.K., C.W. Haeseler, and E.L. Bergman.1983. Growth and foliar elemental composition of Seyval Blanc grapevines as affected by four nutrient solution concentrations of nitrogen, potassium and magnesium. Amer. J. Enol. Vitiulcult. 34:271-277. 